\title{
L'enigma del monastero di Santa Barbara. Tra storia e rappresentazione
}

Francesco Stilo

Abstract

Oggetto del lavoro sono le antiche rovine del monastero di Santa Barbara presso Mammola, le quali, unitamente alle recenti modifiche apportate dall'artista Nik Spatari, rappresentano un esempio di enigmatica connessione tra un passato in inesorabile dissoluzione ed un presente avanguardista in continuo divenire. Un'indagine sotto il profilo storico, finalizzata all'ampliamento e alla sistematizzazione della conoscenza rispetto a una preesistenza immeritatamente poco indagata, si connette e si interseca ad un'operazione di rilievo atta a colmare l'assenza di una documentazione grafica di tipo scientifico sulla struttura. II presente contributo si vuole collocare in quel luogo dove il confine tra la storia, il rilievo, e l'atto del rappresentare si fa labile. Un deep survey, dove la relazione simbiotica tra l'oggetto rilevato ed il rilevatore nasce e si sviluppa a cominciare dalla conoscenza di quella genesi spazio-temporale relativa all'oggetto di cui il disegno diventa condensazione, rivelazione, sintesi.

Parole chiave

rovine, rilievo, Calabria, memoria, storia.

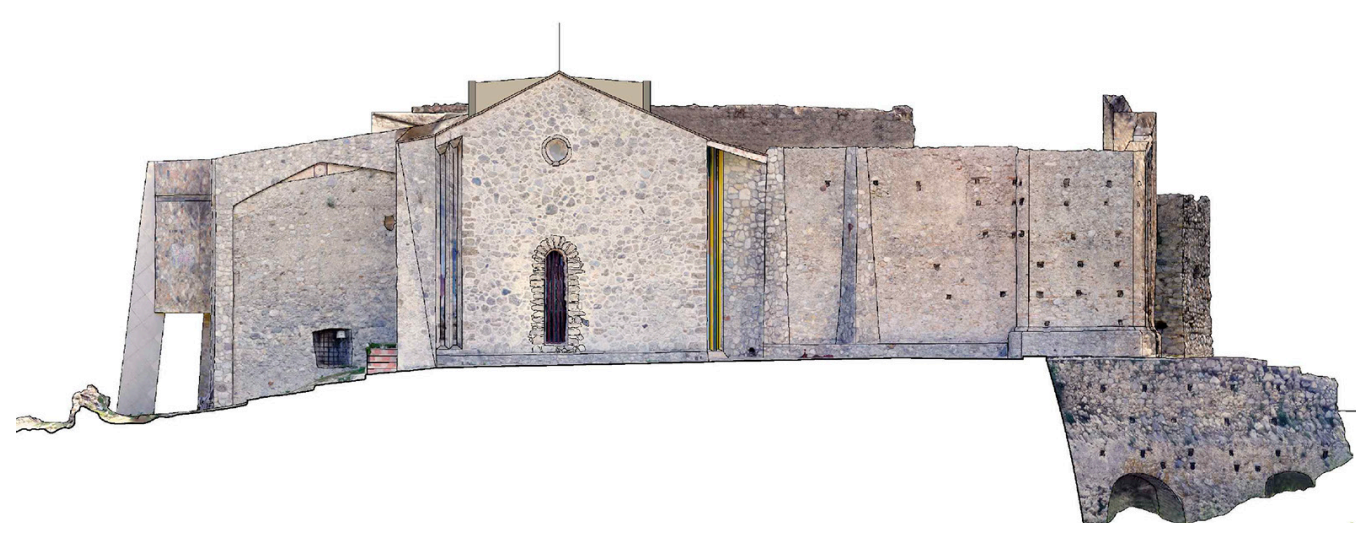




\section{Introduzione}

Studiare le rovine della grangia di Santa Barbara, ubicate nel territorio comunale di Mammola all'interno del parco-museo di arte contemporanea MuSaBa, opera del celebre artista calabrese Nik Spatari, significa confrontarsi con problematiche interne a diverse discipline ed imbattersi in molteplici connessioni [I]. Le imponenti vestigia dell'antico complesso, mescolandosi nella vista al tipico paesaggio del basso Jonio calabrese, all'imponente greto sabbioso del Torbido, alle trasformazioni apportate da Spatari, sono capaci di suscitare nell'osservatore un sentimento che coniuga perfettamente, senza soluzione di continuità, la memoria di un tempo passato e distante alla realtà contemporanea dei giorni nostri, in quel "luogo dello spirito' laddove il tempo si dilata fino ad annullarsi. Sull'acrocoro di S. Barbara, e nei pianeggianti terreni circostanti, coesistono infatti i frammenti di una storia millenaria, testimonianza della rilevanza che il luogo ha assunto nel corso del tempo, brani che si mescolano quasi naturalmente a forme e colori, emanazioni di un'artista visionario che da ormai mezzo secolo ha eletto il sito a propria dimora, proprio laboratorio, proprio scenario di vita (fig. I). Un'aurea di sacralità pervade lo spazio contribuendo così ad arricchire l'enigma irrisolto rispetto alla complessa genesi di un sito su cui convergono molteplici spinte, frequentando il quale si è portati a mettere in discussione alcune delle proprie convinzioni più profonde. Al testo è affidata l'indagine storica, al disegno la rappresentazione di quanto osservato, rilevato e vissuto [2].

\section{Dall'età del ferro al periodo romano}

La vallata del Torbido è un territorio che ha rivestito notevole importanza fin dai tempi più remoti. Volendo sgomberare il campo dalle ipotesi e dalle incertezze, in attesa di nuovi sviluppi e per mantenere la presente trattazione in un ambito rigoroso, è con il rinvenimento di ruderi e resti archeologici venuti alla luce lungo tutto il bacino, autentiche vestigia di una civiltà indigena e Italica preellenica, che possiamo con certezza datare l'antropizzazione dell'area alla prima età del ferro.

Di peculiare importanza sono i resti delle necropoli di Santo Stefano presso Grotteria, e in particolare, per quanto ci riguarda direttamente, di Santa Barbara presso Mammola, nelle aree pianeggianti che circondano l'omonimo acrocoro (fig. 2). La Soprintendenza ar-

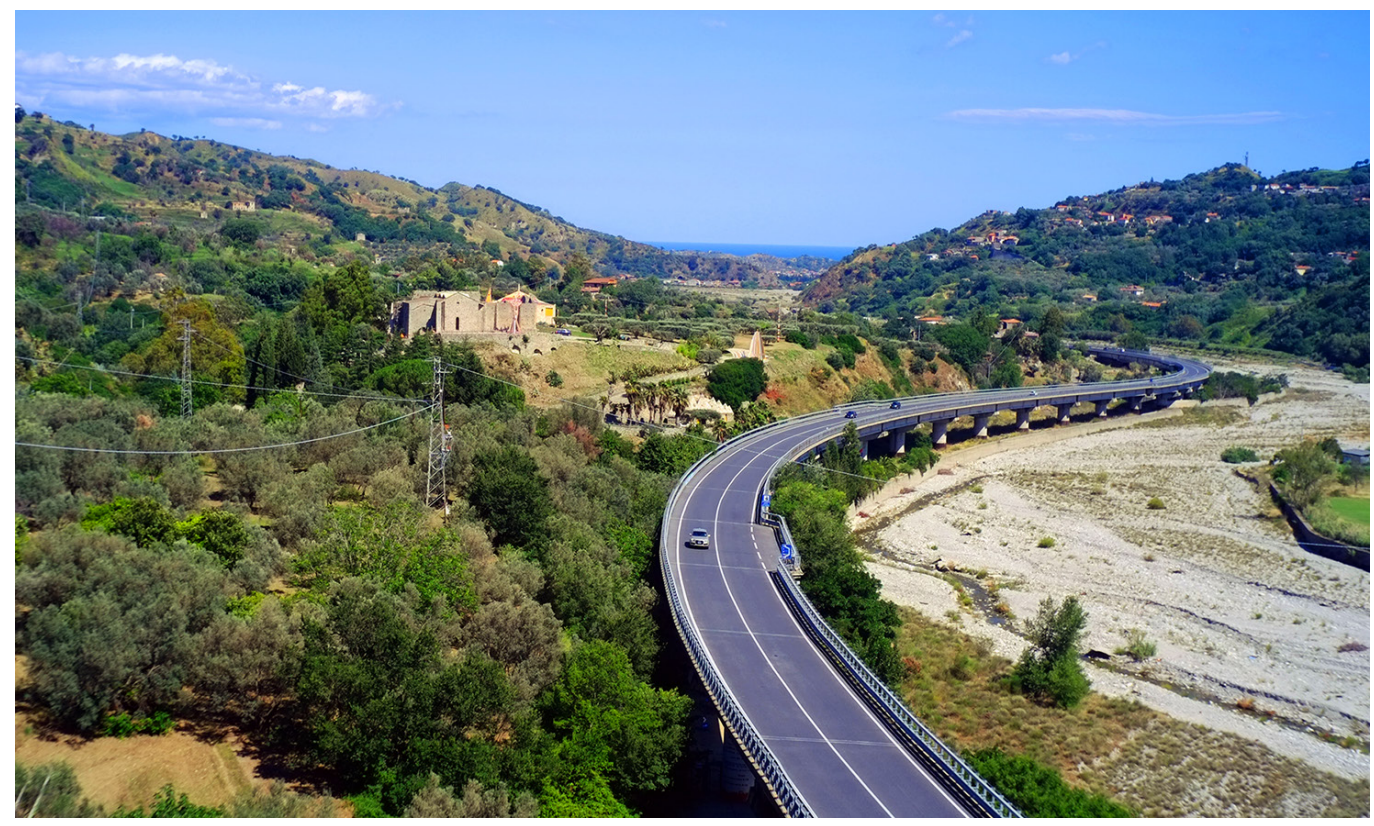


cheologica della Calabria in una nota del 21-12-1979, riferisce dell'eccezionale importanza archeologica del sito: "proteso verso la vallata del Torbido, percorsa anche in antico da una via di attraversamento dell'Appennino, da Locri Epizefiri verso Medma (attuale Rosarno) e Hipponio (oggi Vibo Valentia) [...] si sono rinvenute alcune tombe della prima età del ferro: prevalgono le inumazioni in tombe a fossa, ma sono anche presenti incinerazioni entro pozzetto protetto da pietre" [Gallucci 1983, pp. 2-5] [3].

La nota, compiendo un balzo temporale in avanti, prosegue:" si sono messe in luce strutture pertinenti ad edifici privati del V e IV secolo a.C.; Le tecniche murarie e i materiali (soprattutto frammenti ceramici a vernice nera o acromi) sono assolutamente analoghi a quelli di Locri Epizefiri [...]. II sito archeologico presenta quindi un interesse eccezionale, poiché è la prima volta che nel territorio di Locri si individua e si esplora un centro minore, dipendente da Locri Epizefiri e situato lungo la più comoda via di penetrazione verso l'interno e verso le sub colonie locresi delTirreno. L'abitato di età greca si imposta in un'area precedentemente usata dagli indigeni come necropoli e pone ulteriormente il problema dei rapporti tra le diverse componenti etniche attive nel mondo magnogreco" [Gallucci 1983, pp. 2-5].

Nik Spatari riferisce di alcuni ritrovamenti fortuiti effettuati durante la realizzazione di un acquedotto. Nel tentativo di salvare dalla distruzione certa i reperti, Spatari, insieme ad un ispettore archeologico e ad un gruppo di volontari, iniziò a recuperare alcuni resti. In particolare, vennero ritrovate, insieme al vasellame frantumato, delle urne fittili per la raccolta delle ceneri, la cui somiglianza con quelle etrusche presenti nei musei vaticani è sorprendente. Altri oggetti singolari affiorarono dal sottosuolo, alcuni amuleti fittili la cui forma ricorda i contrappesi utilizzati nei telai, caratterizzati dalla presenza di un misterioso codice sulle quattro facce principali, ed una capretta fittile nera.

Vincenzo Zavaglia riporta che nel 1930, in occasione della realizzazione del tracciato ferroviario Mammola-Marina di Gioiosa Jonica, oggi dismesso, è stata scoperta una vasta necropoli, che lo stesso definisce greco romana, ampiamente compromessa dai dissodamenti agricoli e resecata dallo stesso tracciato. Unitamente alla scoperta in questione sono state rinvenute suppellettili fittili e metalliche. In particolare, si menzionano alcuni manufatti in bronzo, una cuspide di lancia e una fibula quadrata, la cui datazione rimane incerta [Zavaglia 1973, p. 107].

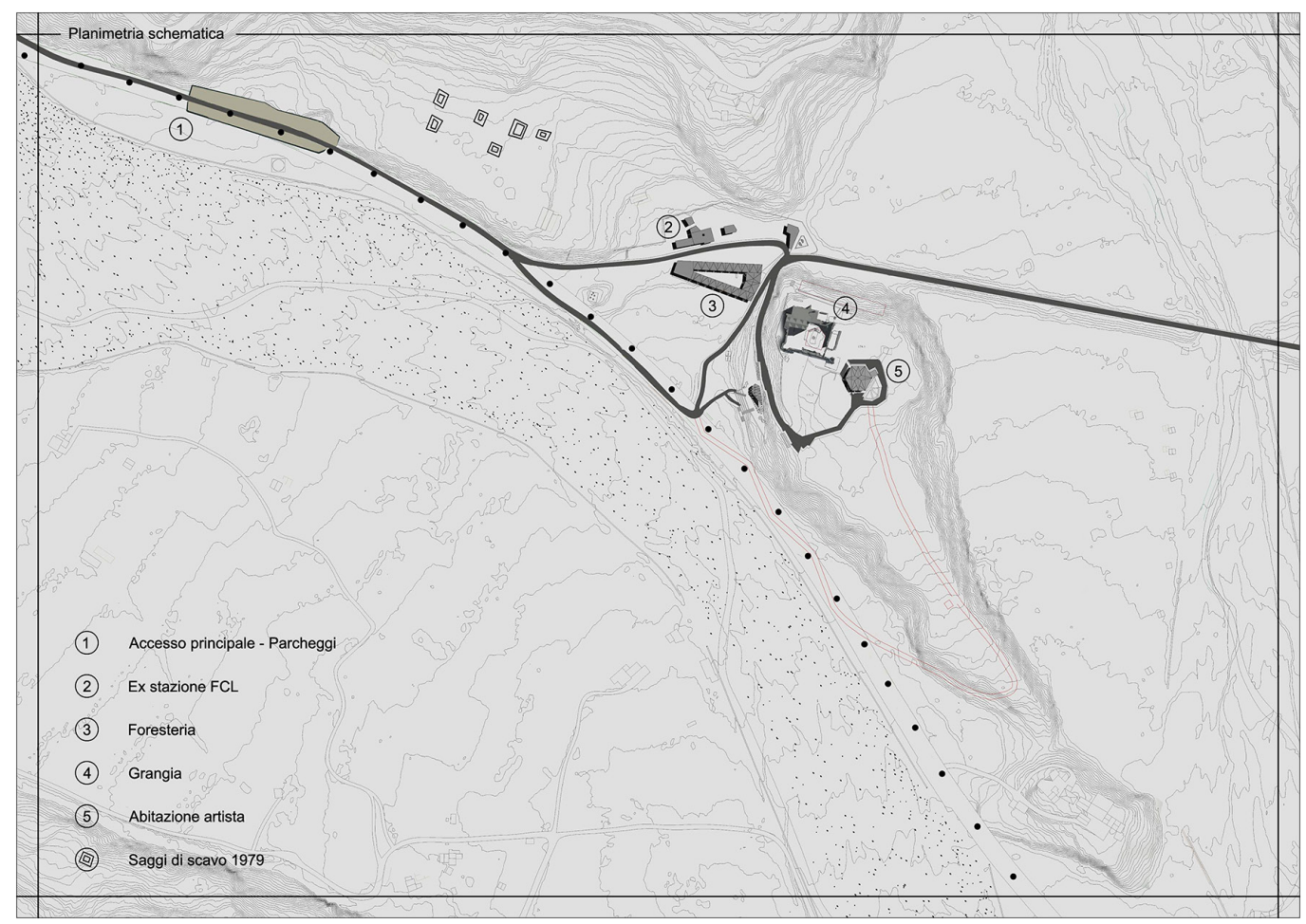




\section{Dal medioevo all'evo moderno}

I fatti che si celano dietro l'origine della grangia di Santa Barbara rimangono ancora oggi parzialmente arvolti nella nebbia. Se è un dato certo che il monachesimo basiliano abbia prosperato lungo la vallata del Torbido, ed in particolare a Mammola, risulta difficile stando ai documenti ad oggi rinvenuti, collocare con esattezza nel tempo il periodo di costruzione di ciò che costituisce l'oggetto del presente studio.

II repertorio dei beni architettonici della provincia di Reggio Calabria [Balbo, Bianchi, Cervellini et al. 1993, p. 324] indica come altra designazione del cenobio quella di San Fantino del Pretoriate, o Proteriate, dalla denominazione che un tempo assumeva il fiume Torbido [Giustiniani I8|6, p. I84], Proteriatum, che il Barrio fa coincidere con il Locanus menzionato da Plinio:"Postea (Sideronum) Proteriatum Flumen navigabile anguillis et torrentinis uber labitur, Locanus olim dictus, cuius meminit Plinius" [Barrio I57I, p. 267].

Fig. 3. Prospetto est della chiesa di Santa Barbara durante le operazioni di pulizia del materia di risulta relativo ai crolli e della vegetazione infestante ad opera di Nik Spatari. Si nota l'abside sventrata. Anni '70 (foto per gentile concessione di Nik Spatari).

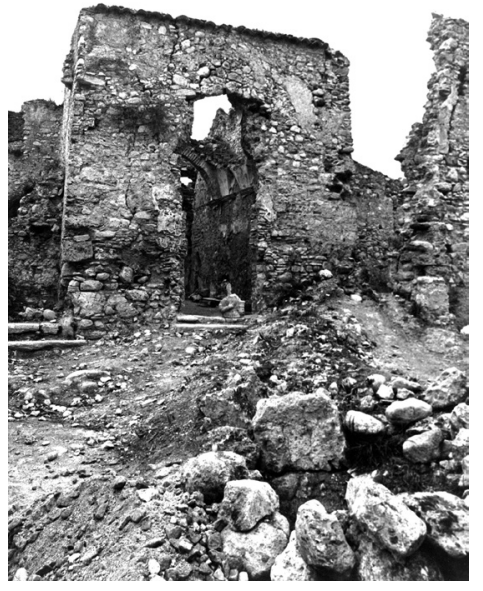

Dello stesso avviso è il Marafioti, il quale riporta: "passata la Grottaria vedemo il fiume Locano, così chiamato da Plinio, il quale dice ch'in questa riviera sono molti fiumi, ma i più notabili sono il fiume Sagra, il fiume Locano. Hoggi il predetto fiume è chiamato Proteriate" [Marafioti |60I, p. I52].

Emilio Barillaro [Barillaro 1977, pp. I5- I8] e Nik Spatari, individuano nel Locano il leggendario fiume Sagra, alla cui foce, nel VI secolo a.C. si svolse la mitica battaglia navale tra le poleis di Locri Epizefiri e di Kroton. Le fonti parlano di una prodigiosa vittoria della prima, la quale, alleata con Reghion, schierava soltanto tra i 10.000 e i 15.000 uomini, contro i 130.000 crotoniati.

II più antico documento fin qui pervenuto che dà notizia del monastero di S. Fantino del Proteriate, è una carta greca del I I 39 trascritta dal Trinchera [Trichera I865, p. I6 I], nella quale si legge che l'Abate Ugo della SS. Trinità diVenosa concesse al notaio di S. Nicodemo due appezzamenti di proprietà del monastero di S. Fantino, un agreste uliveto prossimo all'oratorio di S. Fantino il vecchio ed un piccolo terreno, per il censo annuo, rispettivamente, di una e di mezza cannata di olio [4]. Un altro documento greco del I 194 [Trichera I 865, p. 322] riferisce di una disputa insorta tra alcuni uomini di Grotteria ed il monastero certosino di S. Stefano del Bosco, oggi Certosa di Serra S. Bruno, in merito all'appropriazione di alcune rendite del monastero di S. Fantino da parte di questi ultimi. Lamberto, gran giudice di Calabria dirimette la questione sentenziando che al cenobio di S, Stefano del Bosco, spettasse ogni anno la quinta parte di tutti i redditi, inclusi quelli del monastero di S. Fantino. Ciò proverebbe che l'antico monastero di rito greco era passato sotto le dipendenze della Certosa di Serra San Bruno, divenendo così di rito latino. 
Nel periodo svevo il monastero di S. Fantino ricorre in due documenti del 1213 nei quali vengono citati terreni nelle sue vicinanze, e nel 1232, un altro documento da notizia della cessione in enfiteusi di un fondo del cenobio a Gervaso, preposto del monastero di S. Nicodemo.

Nel periodo angioino, e precisamente nel I 324, l'abate Marco paga come decima la somma di otto tareni, "Frater Marcus abbas S. Phantini solvit tar octo", ma, quattro anni più tardi il monastero dovette trovarsi in difficoltà economica o in decadenza, perché la somma pagata fu molto inferiore.

Intorno al I 365 il monastero passa alle dipendenze del vescovo di Gerace, ma qualche anno dopo, distaccatosi dalla giurisdizione vescovile, diviene grangia del monastero di Arsafia di Stilo. Successivamente a tale data non si hanno più notizie del monastero, se non nel I645, con la nuova denominazione di Santa Barbara [Santagata 2005, pp. 257-259].

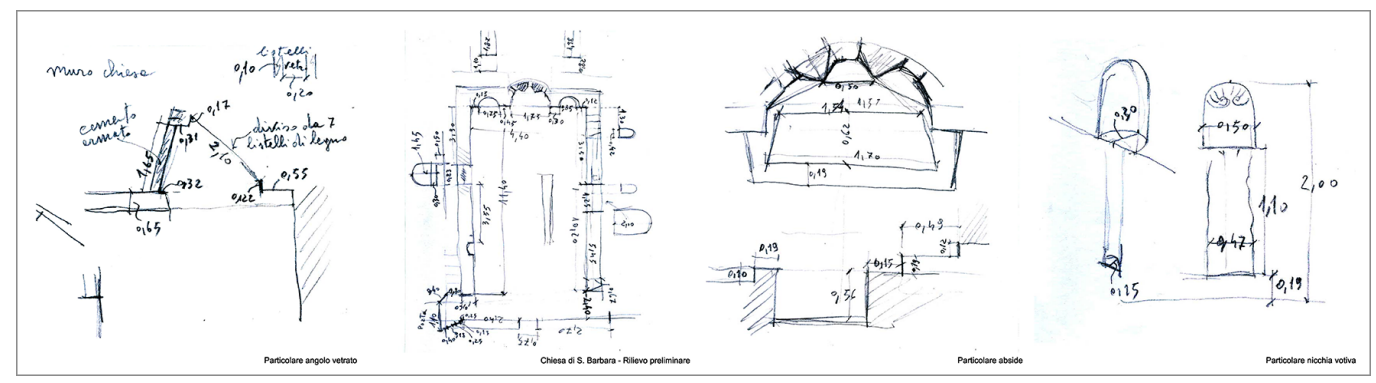

\section{Santa Barbara}

Una carta intestata della Certosa di Serra S. Bruno datata 4 marzo 1992, riferisce della continuità tra il monastero di S. Fantino e la grangia di S. Barbara; si legge: "La Storia comincia nell'alto Medioevo. I monaci italo-greci vi avevano un monastero, ereditato dalla cultura della Magna Grecia. I normanni diedero l'edificio e la tenuta ai certosini. Stava allora sotto il nome si S. Fantino. Dal I 193 fino al I 14 gli abati cistercensi che erano subentrati ai certosini, vi erano padroni. Ritornati i monaci di S. Bruno chiesero all'imperatore Carlo $\mathrm{V}$ la reintegrazione del feudo, in parte alienato dai cistercensi; ciò fu ottenuto per mezzo della stesura della Platea, ora nel museo di Reggio Calabria. I certosini rimasero padroni a S. Barbara fino all'abolizione della feudalità ( 1808 ). Negli ultimi decenni Nik Spatari e Hiske Maas vi si sono installati e vi hanno organizzato un centro artistico".

Dello stesso avviso appaiono Domenico Lupis Crisafi [Lupis Crisafi I887, p. 94], Vincenzo Saletta [Saletta 1969, p. 365], e D'Agostino, e con qualche riserva il già citato Zavaglia. Tuttavia, ad intorbidire le acque, subentrano alcuni indizi contenuti nella platea manoscritta del 1533 che riporta l'elenco dei beni allora appartenenti alla Certosa di Serra S. Bruno [De Leo 1988]. Nella sezione dell'inventario inerente alla grangia di S. Fantino, oltre agli innumerevoli terreni e possedimenti agrari, viene fatta menzione di tre chiese, San Fantino, Santa Maria di Burri e Santa Barbara [5]. Nello specifico, per quanto riguarda Santa Barbara la platea precisa: "In primis dictum monasterium tenet et possidet in eius dominio et potestate eclesiam unam sub vocabulo Sante Barbare, munitam et copertam, sitam et positam in eodem territorio terre Agropterie, in loco vulgariter dicto Santa Barbara, qui est locus montuosus et eminens ubi est queddam planicies terrarum eiusdem monasterii, que ecclesia est sita et posita intus territorium Agropterie, in loco ubi dicitur Santa Barbara, confinatam iuxta viam puplicam que ducit ad terram Agropterie et iuxta terras domaniales dicti monasterii circumcirca dictam ecclesiam, intus quas terras est sita et edificata dicta ecclesia, et eclesia ipsa est libera et exempta ab omni iuridicione episcopale Yiracensi et a quavis alia ecclesia et temporali potestate sed tota est ipsius monasterii"'. 


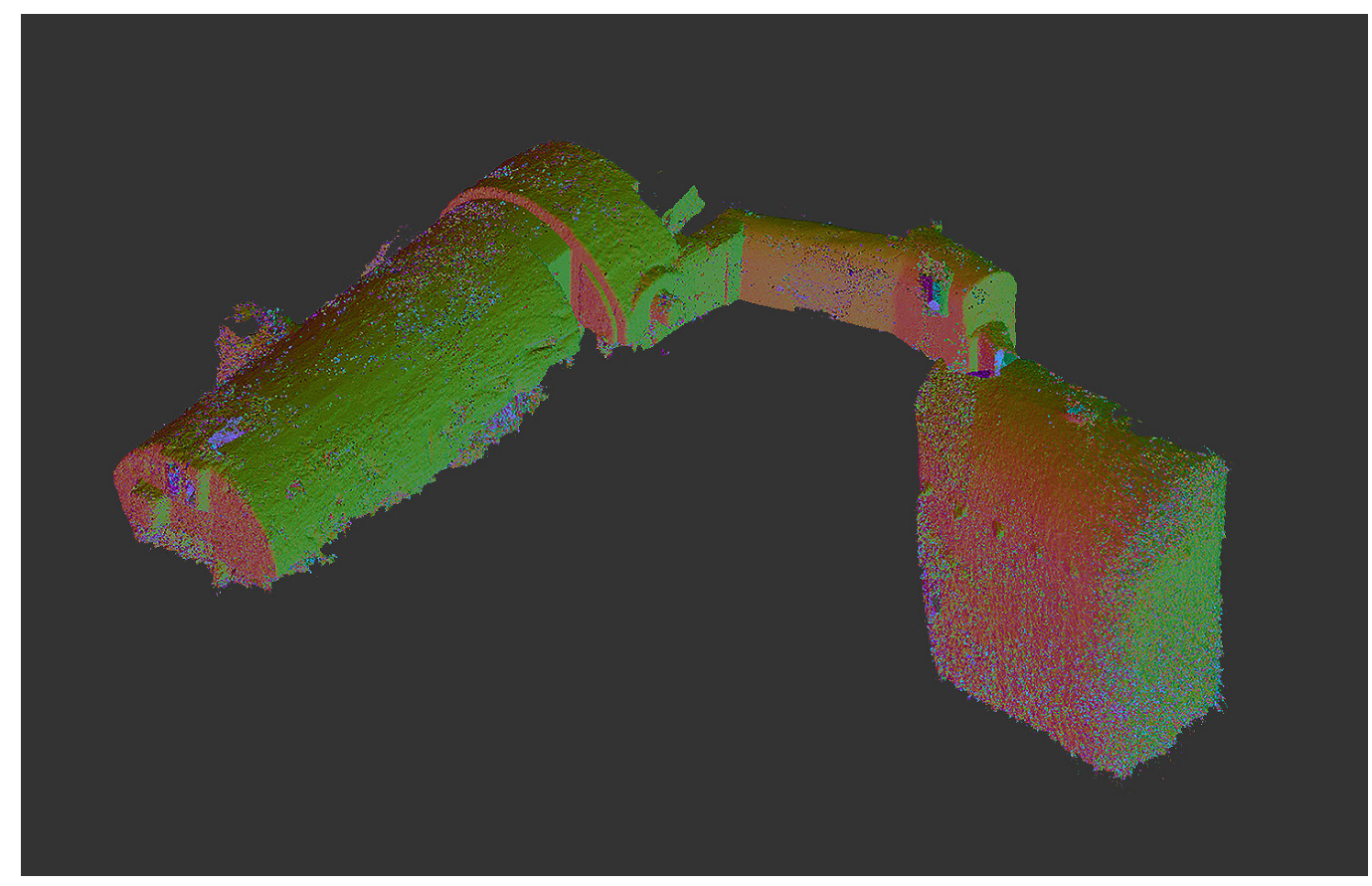

Nella platea, dunque, non viene fatta esplicita menzione delle fabbriche che circondano la chiesetta; è da ciò che i principali sostenitori della non corrispondenza planimetrica tra il monastero di S. Fantino e la grangia di S. Barbara, Emilio Barillaro e in particolare Giuseppe Gallucci, muovono la loro ipotesi, proposta peraltro dal Prof. Pietro de Leo, già ordinario di storia medievale presso l'Università della Calabria, in una missiva del dicembre 1992 [6]. La grangia sarebbe sorta a seguito della dissoluzione dell'antico complesso monastico che si trovava nelle immediate vicinanze, e di cui i ruderi della chiesetta di S. Fantino menzionata nella platea [7] erano parte integrante. I monaci, scartata l'idea di ricostruire la chiesa di S. Fantino, elevarono a caput grangie la chiesa di S. Barbara trasferendovi beni e suppellettili dell'antico cenobio. Fu a partire dalla metà del XVI secolo, che si realizzarono gli interventi strutturali intorno all'oratorio originario, interventi che avrebbero dato luogo alla realizzazione del complesso di cui oggi permangono i resti.

La chiesetta (fig. 3), con abside rivolta ad oriente e prowista di due absidiole minori incluse nello spessore murario, che nel culto greco-bizantino sono da identificarsi quali prothesis e diaconicòn, per analogia potrebbe essere assimilata nelle dimensioni e nelle forme architettoniche, nel suo aspetto originario, alla chiesa di S. Giovannello presso Gerace. Seppure incerta la data della sua edificazione, sembrerebbe non antecedente all'XI secolo. Tracce di un'abside appartenete ad una struttura precedente rimangono ai piedi del prospetto est della chiesa che oggi, dopo aver subito diverse modificazioni ed alterazioni, fino al restauro ed al temerario rifacimento della copertura e di un'abside vetrata, in calcestruzzo armato, effettuato da Nik Spatari, è possibile visitare.

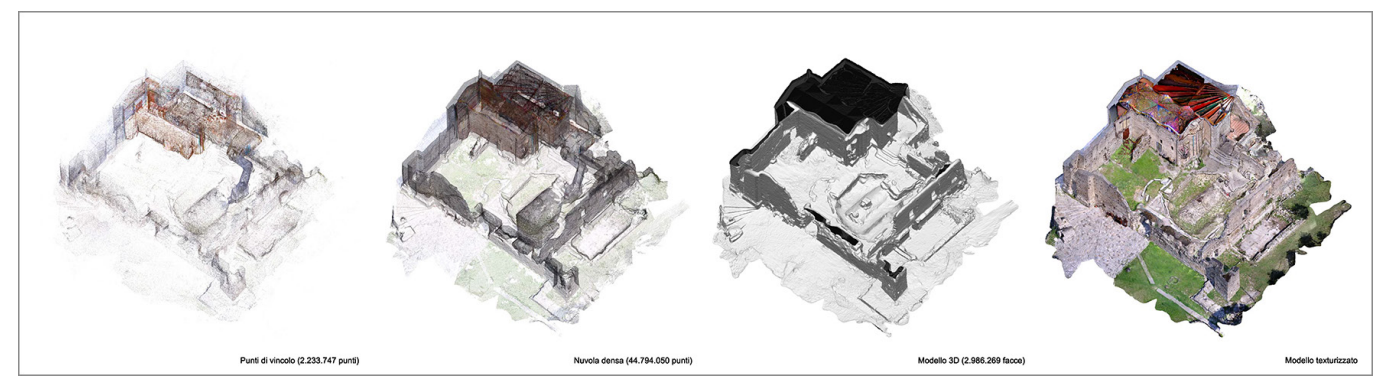




\section{II rilievo}

Allo scopo di colmare il deficit conoscitivo rispetto alla morfologia della struttura, è stato eseguito un rilievo con tecnologia Structure From Motion. L'approccio è stato di tipo integrato, ovvero, in fase di campagna, l'acquisizione delle 2374 immagini costituenti i set successivamente processati, è stata accompagnata dall'esecuzione di eidotipi (fig. 4) e dalla verifica di dettagli e di misure significative con l'utilizzo di longimetri analogici e digitali. Le riprese fotografiche sono state effettuate con fotocamera digitale mirrorless, sensore APS-C da 16,3 megapixel, dotata di obiettivo da $18 \mathrm{~mm}(27 \mathrm{~mm}$ eq. in riferimento al formato full frame). Sono state utilizzate impostazioni manuali per ISO, apertura diaframma e tempo di esposizione, evitando per quanto possibile la variazione degli stessi valori al fine di assicurare l'omogeneità del colore in fase di texturizzazione della mesh. L'uso del flash si è reso necessario nella ripresa degli ambienti ipogei (fig. 5).

Si è considerato opportuno, onde evitare la manifestazione di fastidiosi artefatti, e per snellire per quanto possibile i calcoli, nascondere, mediante l'uso di maschere, tutte quelle porzioni estranee alla scena, come il cielo o altri oggetti di sfondo, ne sono state disegnate 723. Si è proceduto quindi alle operazioni di calcolo suddividendo in 4 set il lavoro [8] onde ottimizzare le risorse hardware disponibili [9]. I set sono stati assemblati, una volta conclusa la fase relativa al calcolo della nuvola densa, attraverso l'individuazione di 3 marker comuni ad ogni coppia elaborata. II risultato si è configurato quale una nuvola densa costituita da

Fig. 7.Vista prospettica interna alla nuvola di punti relativa alla scansione della chiesa. L'opera pittorica riprodotta dal titolo II sogno di Giacobbe è stata eseguita da Nik Spatari.

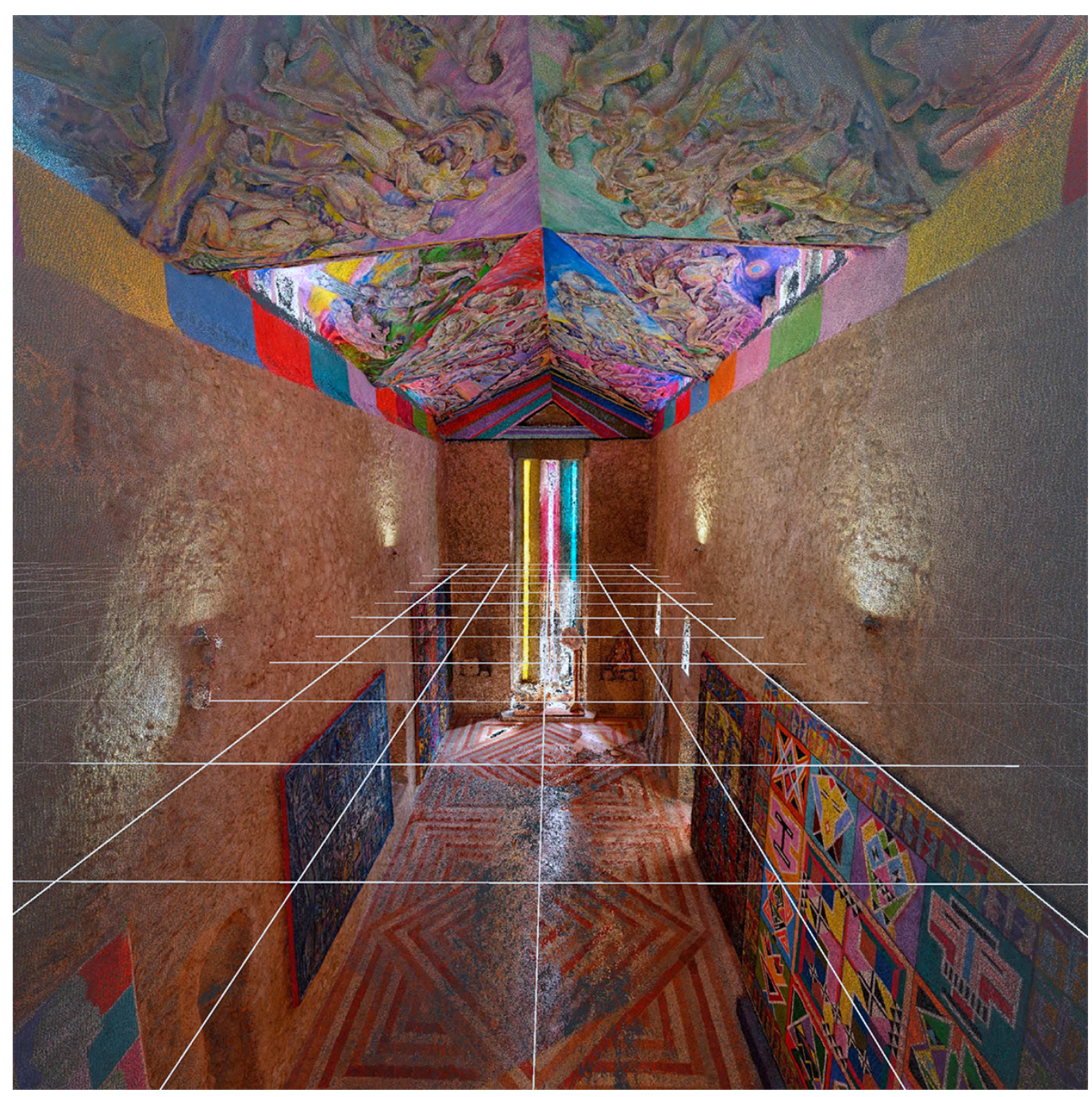




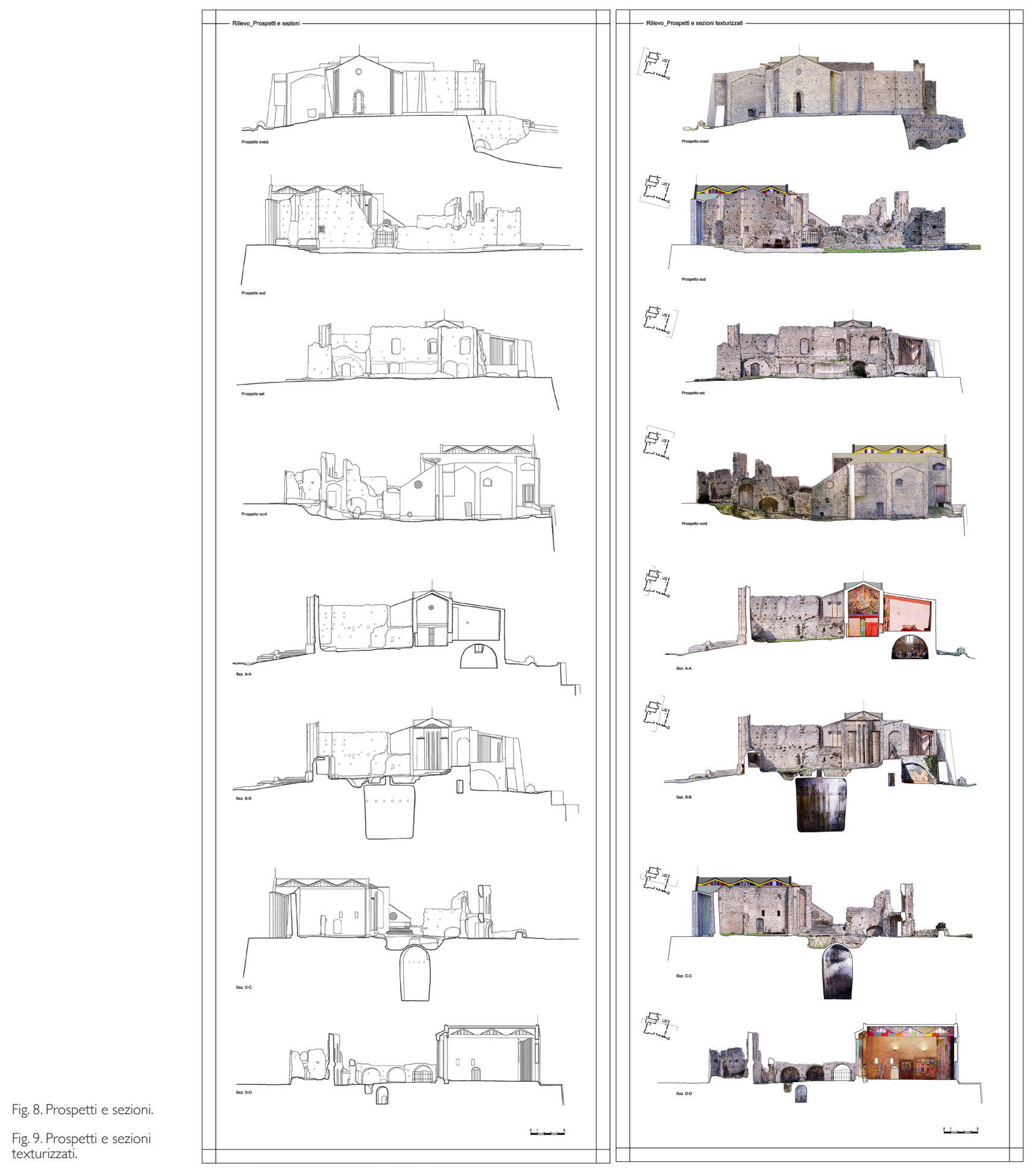




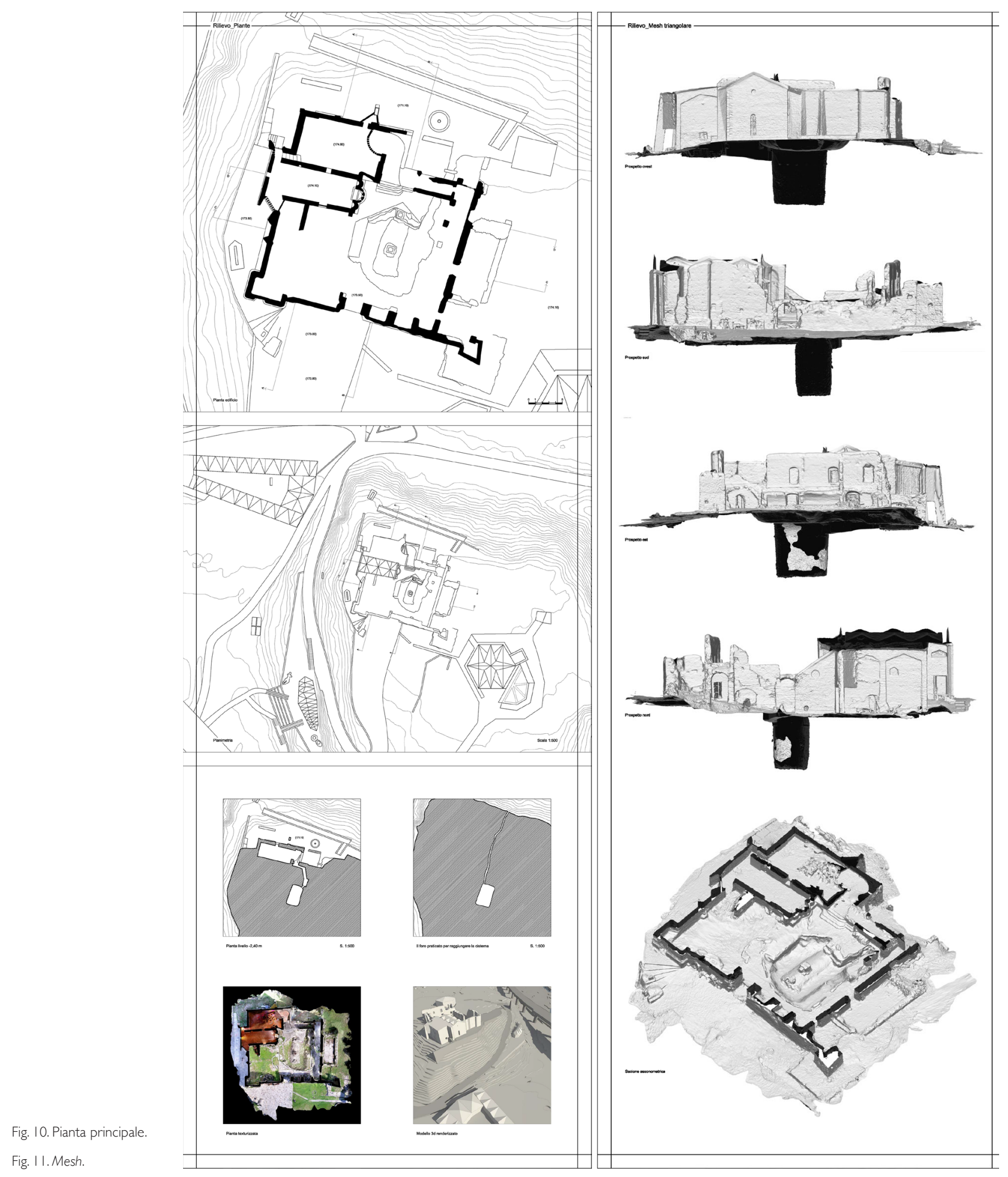


44.794.050 punti aventi l'informazione del colore. Si è proceduto dunque alla generazione della mesh ad una risoluzione di 2.986 .269 facce, ed a una sua successiva texturizzazione (fig. 6).

Nel complesso si è ottenuto un risultato omogeneo, metricamente accurato, ed esaustivo ai fini del processo di post elaborazione, con la presenza di poche e ininfluenti lacune in riferimento alle zone di scarsa accessibilità, ovvero a due pareti della cisterna ipogea ed alla copertura della chiesetta. Rispetto a quest'ultimo punto si è scelto di non colmare tale lacuna attraverso l'uso di altri strumenti, ad es. APR o di 3D eye, perché, trattandosi di una porzione che è stata soggetta ad un intervento di restauro recente ad opera di Nik Spatari, si è potuto disporre facilmente delle informazioni necessarie ad integrare in post-elaborazione la parte.

Gli elaborati prodotti con il software di SFM sono stati successivamente editati attraverso software CAD e programmi per la gestione di immagini raster. Sono così stati disegnati i quattro prospetti, quattro sezioni e le piante dell'edificio (figg. 8, 9, I0). Tali elaborati, si sono così andati ad aggiungere al database digitale composto da nuvole (fig. 7) e mesh (fig. II) oltre che dalla documentazione fotografica.

\section{Note}

[l] Una connessione tra il rilievo e la storia, dove cioè l'indagine storica e il rilievo divengono parti integrante di un'unica operazione. Una connessione temporale tra il passato e il presente, cuciti insieme dal filo dell'arte. Una connessione fisica tra oriente e occidente, segnata dal torrente Torbido quale via di comunicazione tra la sponda ionica e la sponda tirrenica.

[2] Tra gli esiti del rapporto intercorso tra l'autore e il luogo si veda la Tesi di Laurea interdisciplinare in Architettura, discussa nel marzo 2019 presso l'Università degli Studi Mediterranea di Reggio Calabria (dipartimento dArTe) dal titolo L'enigma del museo Santa Barbara - Tra archeologia e contemporaneità. Relatori: prof. Gaetano Ginex, prof. Ottavio Amaro; correlatore: Nik Spatari; studente: Francesco Stilo.

[3] Rispetto a tale considerazione è interessante rilevare come la vallata del Torbido, a causa della propria morfologia, abbia rappresentato una via di collegamento stabile il cui utilizzo da parte dell'uomo si può riscontrare senza soluzione di continuità dai tempi più remoti fino ai nostri giorni con la costruzione della Strada Grande Comunicazione Jonio-Tirreno, vera e propria evoluzione di quel sentiero battuto, percorso dall'homo primigenius e dalle greggi, che ha lasciato il passo alla mulattiera per poi trasformarsi in quel viadotto che caratterizza così fortemente il paesaggio da divenire simbolo della vallata stessa.

[4] "Mense maio, indictione II, anno 6647. Cum ego Hugo Habbas sanctae Trinitas Venusinae essem in (monasterium) S. Phantini Praetoriati, venisti coram me tu dominus Leo notarius S. Nicodemi, et petiisti a me, ut traderem tibi ex legitimi possessionibus monasterii S. Phantini, videlicet (aliquod) ex agrestibus olivetis, ut oleastros insereres sub praestatione. Ego autem tuis precibus motus observitia et beneficia quamplurima, quae praestitisti monasterio et nobis, dedi tibi agreste olivetum proximum oratorio $\mathrm{S}$. Phantinis veteris. Ipsius autem fines sunt: ab oriente sepes praedii praedicti S. Phantini, et discendi recta per sepem hortius que ad viam; ab occidente vero glarea, que descendit a monte, et Criza; a septentrione duo Armi; a meridie via et oleaster maior. Solvere vero ipse tenearis pro memorato (praedio) quotannis monasterio S. Phantini cannatam olei et nihil amplius".

[5] "Inventarium omnium bonorum que tenet et possidet monasterium Santi Stefani Prothomartiris de Boscho, ordinis Cartusiensis, in grangia terre Agropterie, que grangia consistit in tribus eclesiis positis in territorio dicte terre, una sub vocabulo Santi Fantini, alia sub vocabulo Sante Marie de Burri et alia sub vocabulo Sante Barbare, que bona, tam domanialia ipsius monasterii, quam emphiteotica, fuerunt inventariata, citatis emphiteotis et hiis quorum interest et relatis prout in actis curie".

[6] Pietro De Leo (1992). Per l'identità storico monumentale del complesso di Santa Barbara in Mammola. Nota del dipartimento di Storia dell'Università della Calabria del dicembre 1992.

[7] "Bona emphiteotica existentia in grangia santi Fantini in territorio terre Agropterie. In primis dictum monasterium tenet et possidet in eius dominio et potestate, ecclesiam unam, sub vocabulo Santi Fantini, que ecclesia est caput dicte grangie et est nunc diruta et apparent solum vestigia murorum dirutorum, que ecclesia est exempta ab omni iuridicione episcopale et presertim Yracensi et pro ut per privilegia antiqua nobis presentata clare constat fuit dicto monasterio concessa cum omni plenitudine potestatis, tam in temporalibus, quam in spiritualibus et est sita e posita in dicto territorio terre Agropterie, confinata iuxta flumen antiquitus nominatum Prothoriate, quod nunc vulgariter dicitur Flumen Turbidum et iuxta terras ex omni parte dicti monasterii".

[8] Perimetro e prospetti esterni, chiostro e prospetti interni, interno della chiesa e della saletta espositiva, ambienti ipogei.

[9] Si è potuto disporre di personal computer dotato di: CPU AMD FX8350 Eight Core operante ad una frequenza di 4 Ghz; $24 \mathrm{~Gb}$ di memoria RAM; scheda grafica AMD Fire Pro W5 100.

\section{Ringraziamenti}

Ringrazio Nik Spatari e Hiske Maas per la disponibilità dimostrata e per la possibilità offertami rispetto allo studio e alla conoscenza di MuSaBa, la biblioteca D. Topa di Palmi, quanti mi hanno offerto prezioso supporto e collaborazione. 


\section{Riferimenti bibliografici}

Balbo Pier Paolo, Bianchi Alessandro, Cervellini Francesco et al. (1993). Per un atlante della Calabria. Roma: Gangemi Editore. Barillaro Emilio ( I 977). II complesso monastico di Santa Barbara in quel di Mammola. In Brutium, n. 3-4, a. LVI, pp. I5- 8.

Barrio Gabriele ( 57 I). De antiqvitate et situ Calabriae libri qvinqve. Roma: De Angelis.

Bertocci Stefano, Bini Marco (2012). Manuale di rilievo architettonico e urbano. Torino: Città Studi.

Calogero Giuseppe (1964). Storia e cultura della Locride. Messina: ed. La Sicilia.

De Leo Pietro (a cura di). (1998). La platea di S. Stefano del Bosco. Soveria Mannelli: Rubettino.

De Luca Livio (200 I). La fotomodellazione architettonica. Palermo: Flaccovio edizioni.

Gallucci Giuseppe (1978). Finalmente individuata in quel di Mammola la località del monastero di S. Fantino Pretoriate. In Brutium, n. 2, a. LVII, pp. I8-19.

Gallucci Giuseppe (1980). Un oratorio basiliano dimenticato in contrada S. Barbara di Mammola. In Brutium, n. 4, a. LIX, pp. II-13.

Gallucci Giuseppe (1983). Notizie storiche sul monastero di S. Fantino Pretoriate e sul complesso murario della grancia di S. Barbara in quel di Mammola. In Brutium, n. 4, a. LXII, pp. 2-5.

Gallucci Giuseppe (2009). II monastero di San Fantino Pretoriate (note sulla Grancia di Santa Barbara). In Calabria Sconosciuta, n. 124 , a. XXXII, pp. 35-38.

Ginex Gaetano, Trimboli Francesco, Mercurio Sonia, Stilo Francesco (2019). II limes della Calabria bizantina. Tracce, percorsi e vie. In Archistor extra, 6, 2019 , pp. 214-227.

Giustiniani Lorenzo ( 18 | 6). Dizionario geografico ragionato del regno di Napoli. Napoli: Stamperia Giovanni De Bonis.

Lupis Crisafi Domenico (1887). Cronaca di Grotteria: dalla sua fondazione fino all'anno 1860. Gerace Marina: Tip. Michele Caserta \& C.

Marafioti Girolamo ( 60 I). Croniche et antichità di Calabria. Padova: Ad istanza de gl'Vniti.

Saletta Vincenzo (1969). San Nicodemo del Cellerano. In Studi Meridionali, fasc. III-IV, a. II.

Santagata Giuseppe (2005). Compendio storico-artistico della monumentalità chiesastica calabrese. Locri: Pancallo Editore.

Stilo Francesco (2019). L'enigma del museo di Santa Barbara. Tra archeologia e contemporaneità. Tesi di Laurea in Architettura, Università degli Studi Mediterranea di Reggio Calabria. Relatori: prof. Gaetano Ginex, prof. Ottavio Amaro; correlatore: Nik Spatari.

Trinchera Francesco (1865). Syllabus Graecarum Membranarum. Napoli:Typis Josephi Cataneo.

Zavaglia Vincenzo (1973). Mammola. Chiaravalle Centrale: Frama Sud.

\section{Autore}

Francesco Stilo, Università degli Studi Mediterranea di Reggio Calabria, francesco.stilo@unirc.it

Per citare questo capitolo: Stilo Francesco (2020). L'enigma del monastero di Santa Barbara. Tra storia e rappresentazione/Santa Barbara's monastery enigma, between history and representation. In Arena A., Arena M., Brandolino R.G., Colistra D., Ginex G., Mediati D., Nucifora S. Raffa P. (a cura di). Connettere. Un disegno per annodare e tessere. Atti del $42^{\circ}$ Convegno Internazionale dei Docenti delle Discipline della Rappresentazione/Connecting. Drawing for weaving relationships. Proceedings of the 42th International Conference of Representation Disciplines Teachers. Milano: FrancoAngeli, pp. 2736-2757. 


\section{Santa Barbara's Monastery Enigma, between History and Representation}

Francesco Stilo

\section{Abstract}

The subject of this essay are the ancient ruins of Santa Barbara's monastery of Mammola (RC), which together with the latest enhancements made by the artist Nik Spatari, represent an enigmatic bridge between the inevitable dissolution of the past and an avant-gardist present that is constantly evolving. A deep historical investigation will be conducted in parallel with a survey operation, to open up the knowledge on a topic that hasn't been properly inspected in time, whilst providing a graphic documentation of this structure that is lacking in the records. This investigation aims to become a deep survey, where the symbolic relationship between the object of the findings and the person who found it, unfolds in the act of drawing.

Keywords

ruins, survey, Calabria, memory, history.

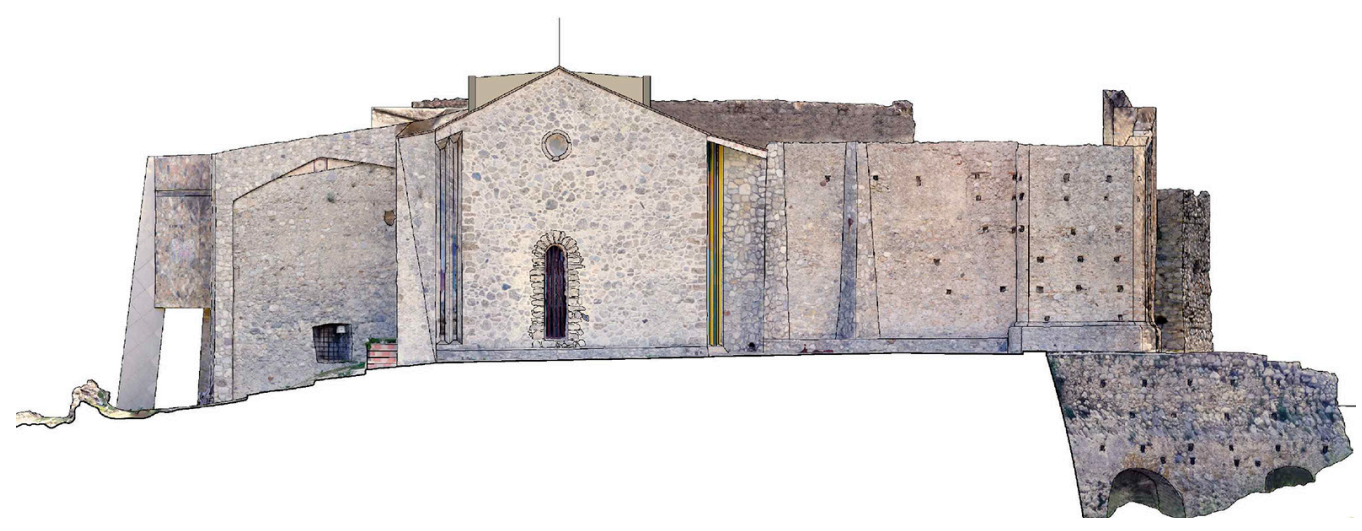




\section{Introduction}

Studying the ruins of Santa Barbara's grangia (a farm-monastery type), located inside the museum park of contemporary Art MuSaBa, involves confrontations with internal problems and disciplines, while figuring out in parallel different connections [I]. The majestic ruins of this ancient building blend perfectly into the typical Calabrian-Jonian landscape, into the sandy shore of the riverTorbido, into the transformations applied by Spatari. This natural mix of colours and historical artefacts create in the heart of the observer a feeling of timeless and eternal spirituality. On Santa Barbara's upland and on the plains around it, fractions of thousand-year old history and the visionary works of an artist coexist this is the place where an artist chose to make his laboratory, his home, and his life-long scenery (fig. I).

A sense of sacredness surrounds this space, strengthening the unresolved enigma about the origin of this place, and naturally making the observer question his own believes on the matter.

The text is entrusted with the historical investigation, the drawing with the representation of what has been observed, detected, experienced [2].

\section{From the Iron Age to the Roman times}

The Torbido valley is a territory that has been of considerable importance since ancient times. Wanting to clear the field of hypotheses and uncertainties, pending new developments and to keep the present discussion in a rigorous context, it is with the discovery of ruins and archaeological remains that came to light along the entire basin, authentic vestiges of an indigenous civilization and Italic pre-Hellenic, which we can with certainty date the anthropization of the area to the early Iron Age.

Of particular interest are the remains of Santo Stefano's necropolis in Grotteria and the remains of Santa Barbara in Mammola, discovered in the plains that surround the upland of the same name (fig. 2). The Superintendence of Archaeology in Calabria, talks about the great importance of this site in a note from the 21 - 12- 1979:" Extended towards the Torbido valley, traversed in ancient times by a crossing path of the Appennino, from Locri Epizefiri

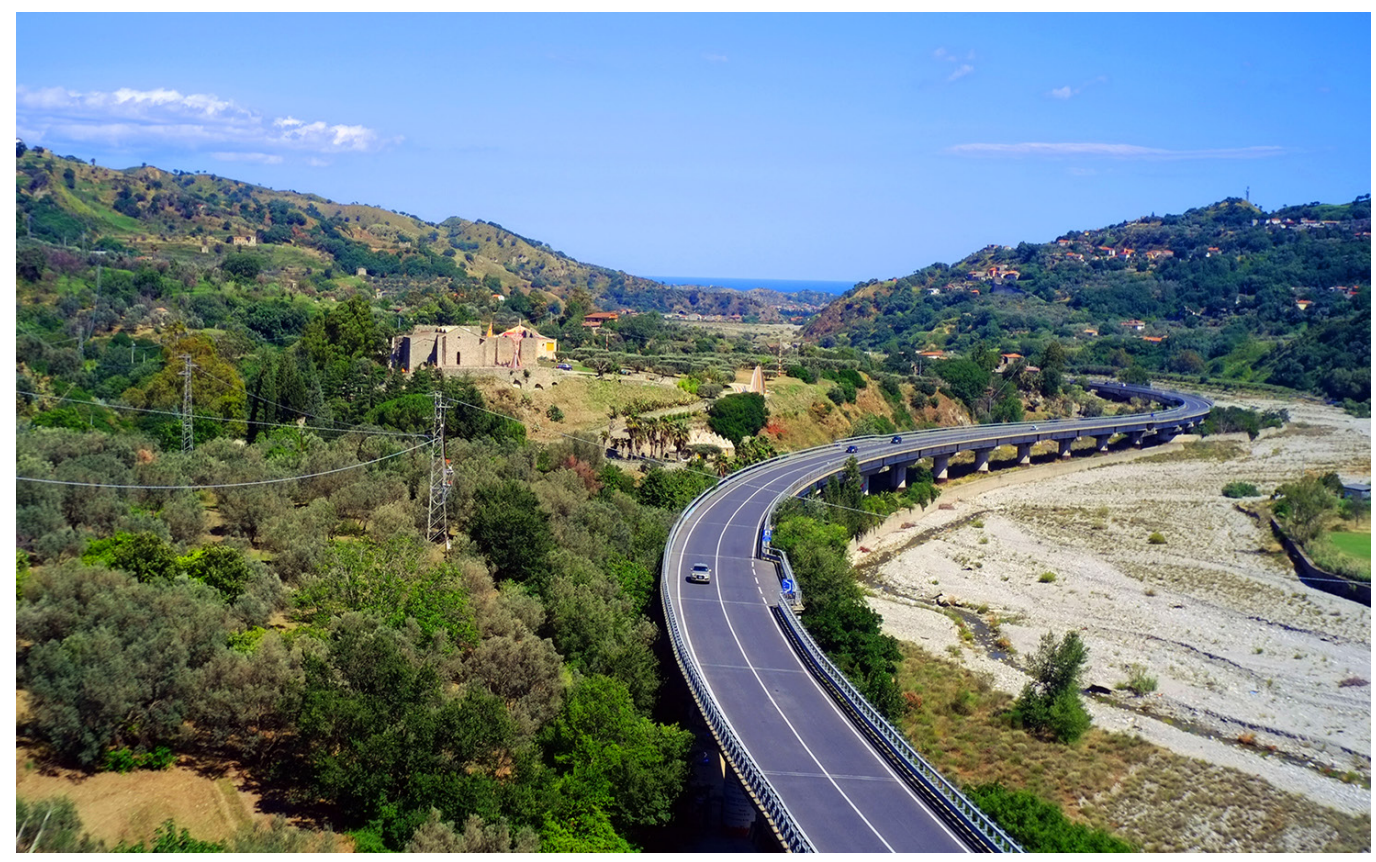


to Medma (currently Rosarno) and Hipponio (today Vibo Valentia) [...] several tombs from the early Iron Age got discovered: mostly involving burials in graves, but also examples of cremations in graves, protected by stones" [Gallucci 1983, pp. 2-5] [3].

This note, goes on further:"some structures of private buildings from the $V$ and IV Century b.C. got brought back up; The building techniques and the materials used (especially fragments of ceramics, plain or with black varnish details) are totally comparable with the ones founded in Locri Epizefiri [...] the archaeological site is of exceptional interest: it's the first time that in Locri we can observe a minor settlement, still dependent on Locri Epizefiri but located in the most comfortable path towards the inland and their sub-colonies on the Tirrenian side. The area inhabited during the Greek times is placed in an area previously used as necropolis by indigenous populations and make us question, again, about the problems of relationships between different ethnicities in the Magna Greece world" [Gallucci 1983, pp. 2-5].

Nick Spatari told us about some accidental findings, brought to light during some construction works on an aqueduct. Attempting to save these findings from a certain destruction, Spatari, an archaeological supervisor and some volunteers, started to recovery some of the rests. Among shattered pottery, some urns incredibly similar to the Etruscan ones of the Vatican Museums got recovered. Other particular objects of common use emerged from the surface, like some sort of clay amulets whose shape reminds of the weights used for the looms, which were showing on the four facets a mysterious code, or a small clay goat.

Vincenzo Zavaglia says that in 1930, in occasion of the constructions of the railway Mammola-Marina di Gioiosa Jonica (which is today abandoned), a supposedly Greek-roman big necropolis got discovered, which was greatly compromised by the agricultural tillage across the years. Together with this discovery, miscellaneous furnishings in clay and metals got brought to light, especially some bronze manufactures, the point of a spear and a squared clasp, whose dating is still unknown [Zavaglia 1973, p. 107].

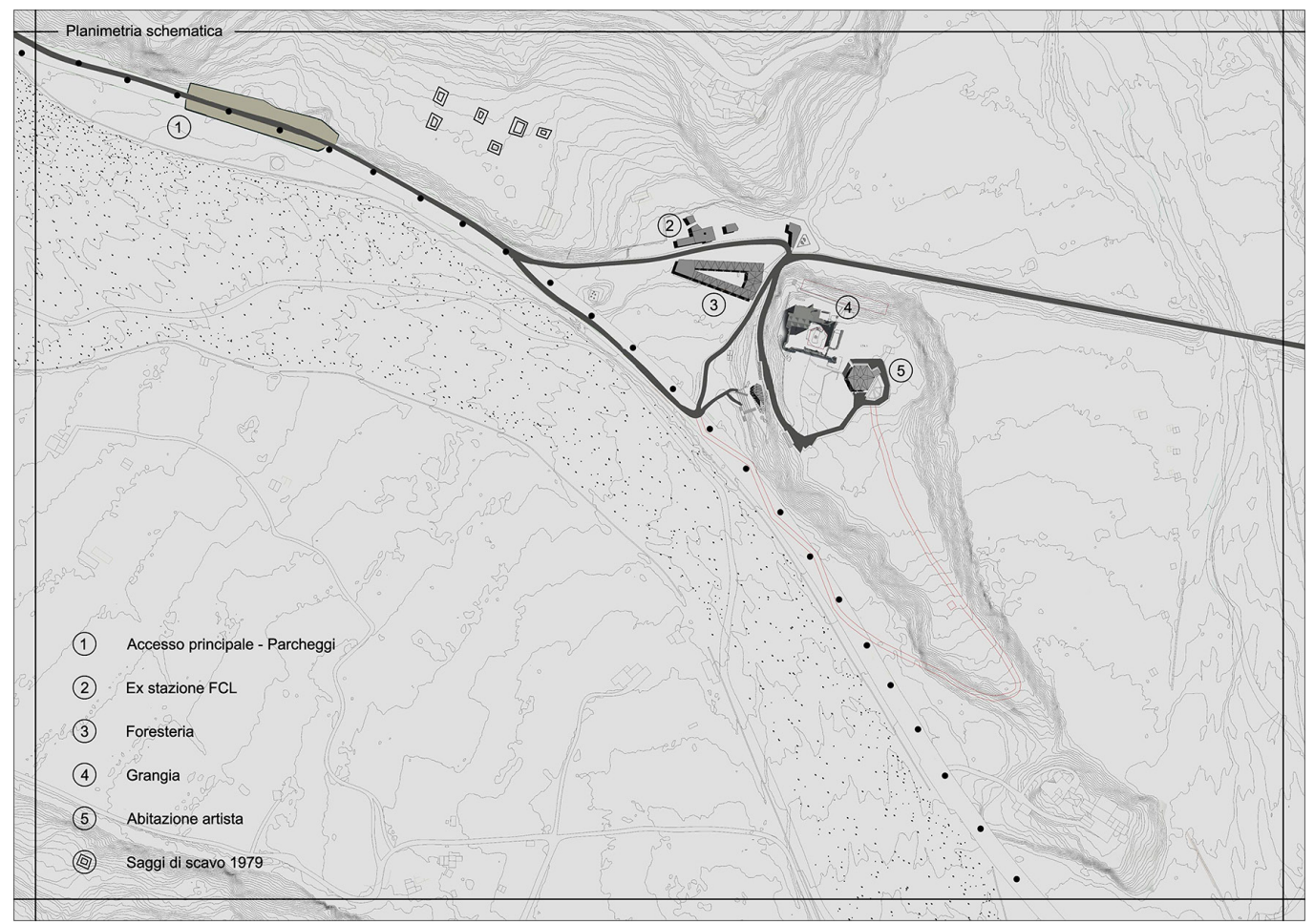




\section{From the Middle age to the modern times}

The history behind the origin of Santa Barbara's monastery are still today uncertain. Even though monasticism was widely diffused along the Torbido valley, especially in Mammola, according to the official records, it's still quite hard to exactly define the construction's dating of our subject of matter.

Reggio Calabria's architectural heritage portfolio [Balbo, Bianchi, Cervellini et al. 1993, p. 324] indicates as other possible nomination for the coenobium San Fantino del Pretoriate or Proteriate (the old name used for the Torbido river [Giustiniani 1816, p. I 84] Proteriatum), which Barrio [Barrio I57I, p. 267] corresponds with the Locanus river, mentioned by Plinio: "Postea (Sideronum) Proteriatum Flumen navigabile anguillis et torrentinis uber labitur, Locanus olim dictus, cuius meminit Plinius" [Marafioti I60 I, p. I52].

Fig. 3. East elevation of the church of Santa Barbara during the cleaning of the material resulting from the collapses and weed vegetation by Nik Spatari. Note the gutted apse. 70 Photo courtesy of Nik Spatari.

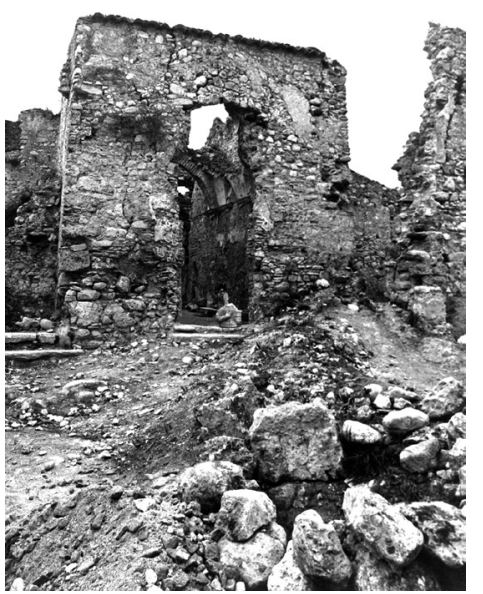

Of the same opinion, is Marafioti who says: "Once we overcame the Grottaria, we saw the Locano river, so called from Plinio, who says that in this coastline there are many rivers, but the most noticeable are the river Sagra, river Locano. Today, the mentioned river is called Proteriate".

Emilio Barillaro [Barillaro 1977, pp. I5- I8] and Nick Spatari, believes the legendary Sagra river to actually be the Locano, where at its mouth during the VI Century b.C., took place the famous naval battle between Locri Epizefiri and Kroton. The sources report an exceptional winning of Locri Epizefiri which, in alliance with Reghion, had put on its army only between I 0.000 to $\mid 5.000$ men, against the $\mid 30.000$ from the Kroton side.

The most ancient document that got to us, speaking about the monastery of S. Fantino del Proteriate, is a Greek paper dated back to I 139, transcribed by Trinchera [Trichera I865, p. I6I]. In this paper was reported that abbot Ugo from the SS Trinità di Venosa gave away two lots of land, belonging to the monastery of S. Fantino: a rustic olive grove in proximity of S. Fantino and a small piece of land, both given away to pay the yearly taxes in exchange, a part of olive oil production [4]. Another Greek document from the II 94 [Trichera 1865, p. 322] talks about an argument between some men from Grotteria and the representative from the Cartusian monastery of S. Stefano del Bosco (today Certosa di Serra S. Bruno), regarding the appropriation by the people of the Cartusian monastery, of part of the income coming from the monastery of S. Fantino. Lamberto, great judge of justice in Calabria, settled the argument assigning to the monastery of S. Stefano del Bosco, a fifth of all the earnings, including the ones coming from the monastery of S. Fantino. This event would prove that the ancient monastery of Greek rite, when moving under the dependency of the Abbey of Serra San Bruno, became one of Latin rite. 
During the Swabian period, the monastery of S. Fantino is mentioned in two documents from the 1213 , where some lots of land in the surroundings are mentioned and in another document in 1232 about giving awayin usufruct a fund of the monastery to Gervaso, an appointed figure from the monastery of S. Nicodemo.

During the Angevin period, specifically in 1324, the abbot Marco payed the sum of eight Tareni as a tax decima," "Frater Marcus abbas S. Phantini solvit tar octo", and four years later the monastery founded itself in economic difficulties because the money payed by the abbot was much lower than what it was meant to be.

Around I364, the monastery became dependent on the bishop of Gerace. Just few years later though, it detached from the episcopal jurisdiction becoming the monastery of Arsafia di Stilo. There is no more information on the records about the monastery until in 1645, when his name changes to Santa Barbara [Santagata 2005, pp. 257-259].

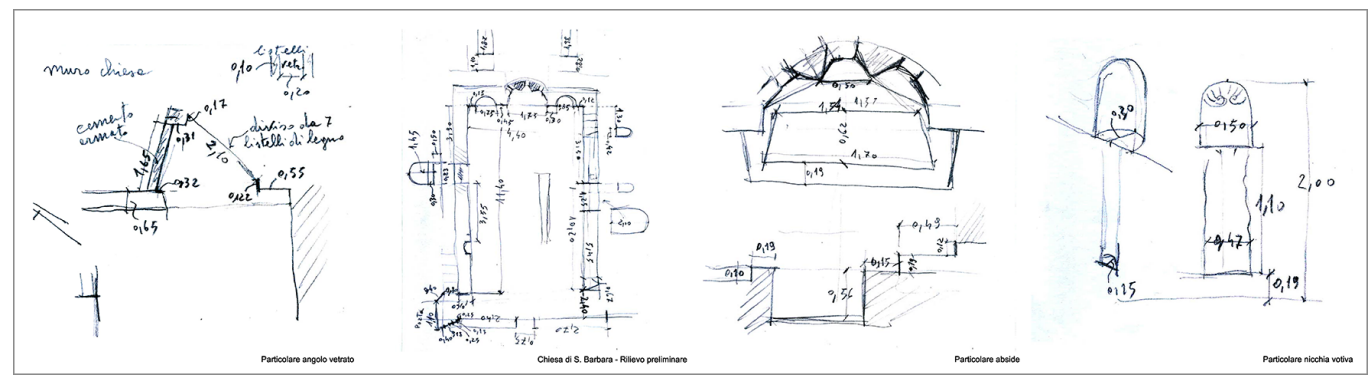

\section{Santa Barbara}

A letter head belonging to the Certosa of Serra S. Bruno, dated on the 4th March 1992, talks about the connection between the monastery of S. Fantino and the "grangia" of S. Barbara:

"The story starts during the early Middle Ages. The Italian-Greek monks had a monastery, inherited from the culture of Magna Grecia.The Normans donated the building and the land to the Carthusians. It was called S. Fantino back then. From II93 to I5I4, the Cistercian abbots took over from the Carthusians and became the owners. Once the monks from $\mathrm{S}$. Bruno came back, they asked the emperor Carlo $V$ for the feud to be reintegrated, as it got partially isolated while the Carthusians were running it; this happened thanks to the writing of the 'Platea' census, now stored in the museum of Reggio Calabria. The Carthusians stayed owners of S. Barbara until the official abolition of feudalism (I 808). In the last decades, Nik Spatari and Hiske Maas have settled there and set up an art centre".

Domenico Lupis Crisafi [Lupis Crisafi I887, p. 94], Vincenzo Saletta [Saletta 1969, p. 365], E. D'Agostino and, although subject, the previously mentioned Zavaglia are supporting the same opinion. However, there are some clues that muddy the waters in the hand-written census from the 1533, where a detail of the properties belonging to the Certosa of Serra S. Bruno is listed [De Leo 1988]. In the section about the inventory of S. Fantino monastery, along with the innumerable lands and agricultural properties, three churches are mentioned: San Fantino, Santa Maria di Burri e Santa Barbara [5]. For Santa Barbara specifically, the census states: "In primis dictum monasterium tenet et possidet in eius dominio et potestate eclesiam unam sub vocabulo Sante Barbare, munitam et copertam, sitam et positam in eodem territorio terre Agropterie, in loco vulgariter dicto Santa Barbara, qui est locus montuosus et eminens ubi est queddam planicies terrarum eiusdem monasterii, que ecclesia est sita et posita intus territorium Agropterie, in loco ubi dicitur Santa Barbara, confinatam iuxta viam puplicam que ducit ad terram Agropterie et iuxta terras domaniales dicti monasterii circumcirca dictam ecclesiam, intus quas terras est sita et edificata dicta ecclesia, et eclesia ipsa est libera et exempta 


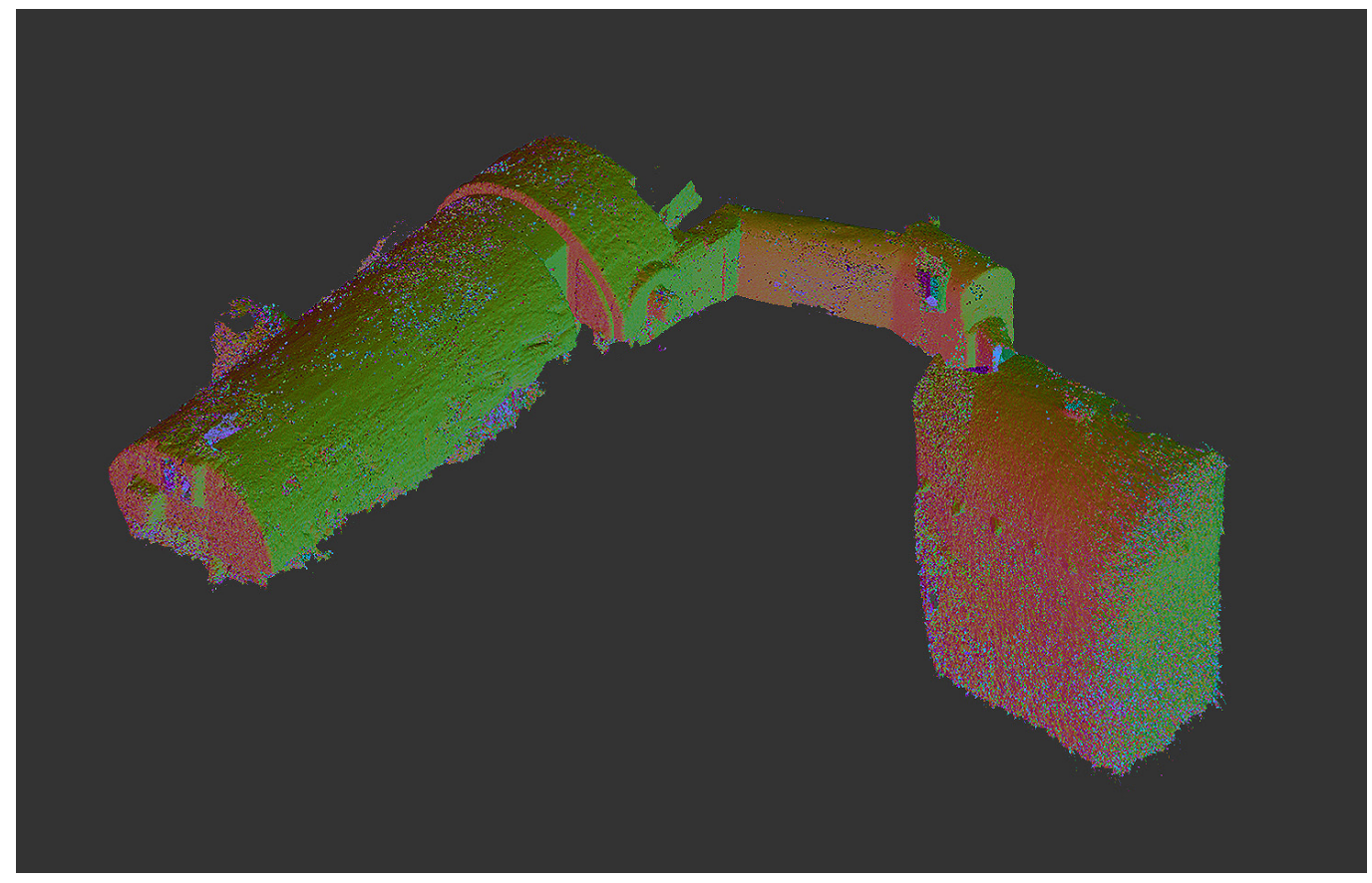

ab omni iuridicione episcopale Yiracensi et a quavis alia ecclesia et temporali potestate sed tota est ipsius monasterii".

In this census the factories surrounding the church are not mentioned and this is where the debate on the not corresponding planimetry between the monastery of S. Fantino and the one from S. Barbara starts. Especially Emilio Barbaro and Giuseppe Gallucci, pushed for this hypothesis with the support of the Prof. Pietro de Leo, specialised in Medieval history at the I'Università della Calabria, with a paper already back in December 1992 [6].

The grangia was built after the dissolution of an ancient monastic complex that used to be in the same area. The ruins of the little church of S. Fantino mentioned in the census [7], were part of this complex. The monks disregarded the idea of re-building the church of S. Fantino by elevating the $\mathrm{S}$. Barbara's one as main church of this complex, and by moving in material goods and furnishings of the ancient coenobium. The construction works around the original parish started some time around the middle of the $\mathrm{XVI}$ century, setting up the same complex of buildings whose ruins we still see today.

The little church (fig. 3) has an apse facing East and two smaller absidioles included in the wall thickness as per the Greek-byzantine cult, where they are called prosthesis and diaconicon. This church could be compared in shapes and dimensions, in its original aspect, to the one of S. Giovannello in Gerace. The building date is uncertain, but everything points out to it being prior to the XI century: even though several alterations in the overall structure and renovations took place (like the restoration of the roofing and of a glazed apse in reinforced concrete, made by Nik Spatari), on the east front of the church that we see today, there are still some traces of an apse belonging to a previous structure.

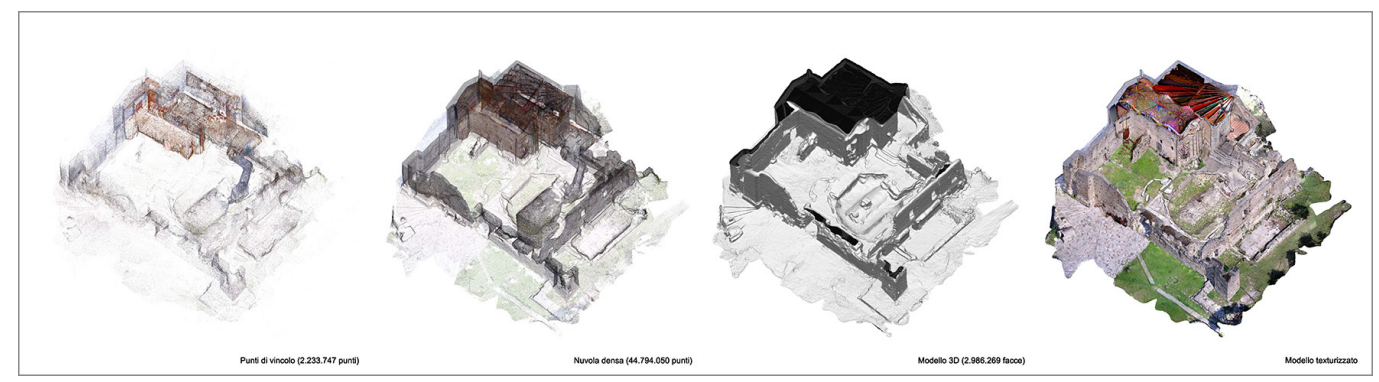




\section{The survey}

In order to fill in the lack of knowledge about the morphology of the structure, a relief using the technology Structure From Motion took place. The approach has been incremental and integrated: during the acquisition of 2374 frames that the software would have afterwards processed, the execution of sketches (fig. 4) and the validation of the relevant measurements using both analogic and digital meterstick has been ran in parallel. The photo shootings have been done with a mirrorless camera, APS-C sensor and 16,3 MPx, using a $18 \mathrm{~mm}$ lens (corresponding to a $27 \mathrm{~mm}$ with respect to full frame sensor). The shooting has been manual in setting up ISO, exposition and aperture, trying to keep those values stable to grant consistency in colour during the texturing phase of the mesh. The usage of flashlights has been necessary in underground shootings (fig. 5).

In order to simplify the calculations, it was considered appropriate, in order to avoid the appearance of annoying artifacts, and to streamline calculations as much as possible, to hide, through the use of masks, all those portions extraneous to the scene, such as the sky or other background objects; 723 masks were designed. The measurement operation has been set up dividing in 4 sets the work [8] to optimise the usage of the hardware [9] available. After the calculation of the dense cloud, the sets have been assembled identifying $3 \mathrm{com}$ mon points to each processed couple. As a result, a dense cloud made of 44.794 .050 points

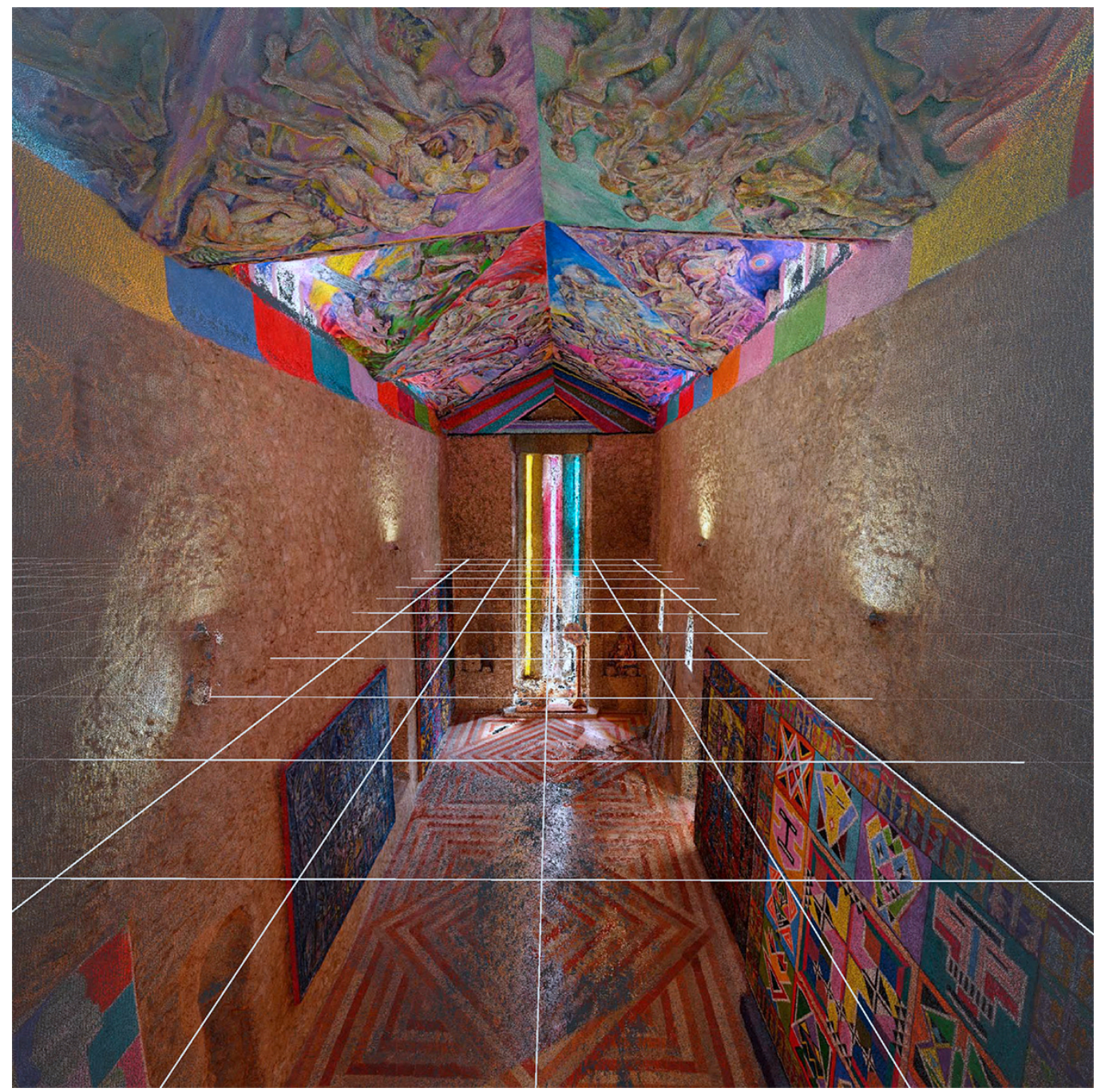




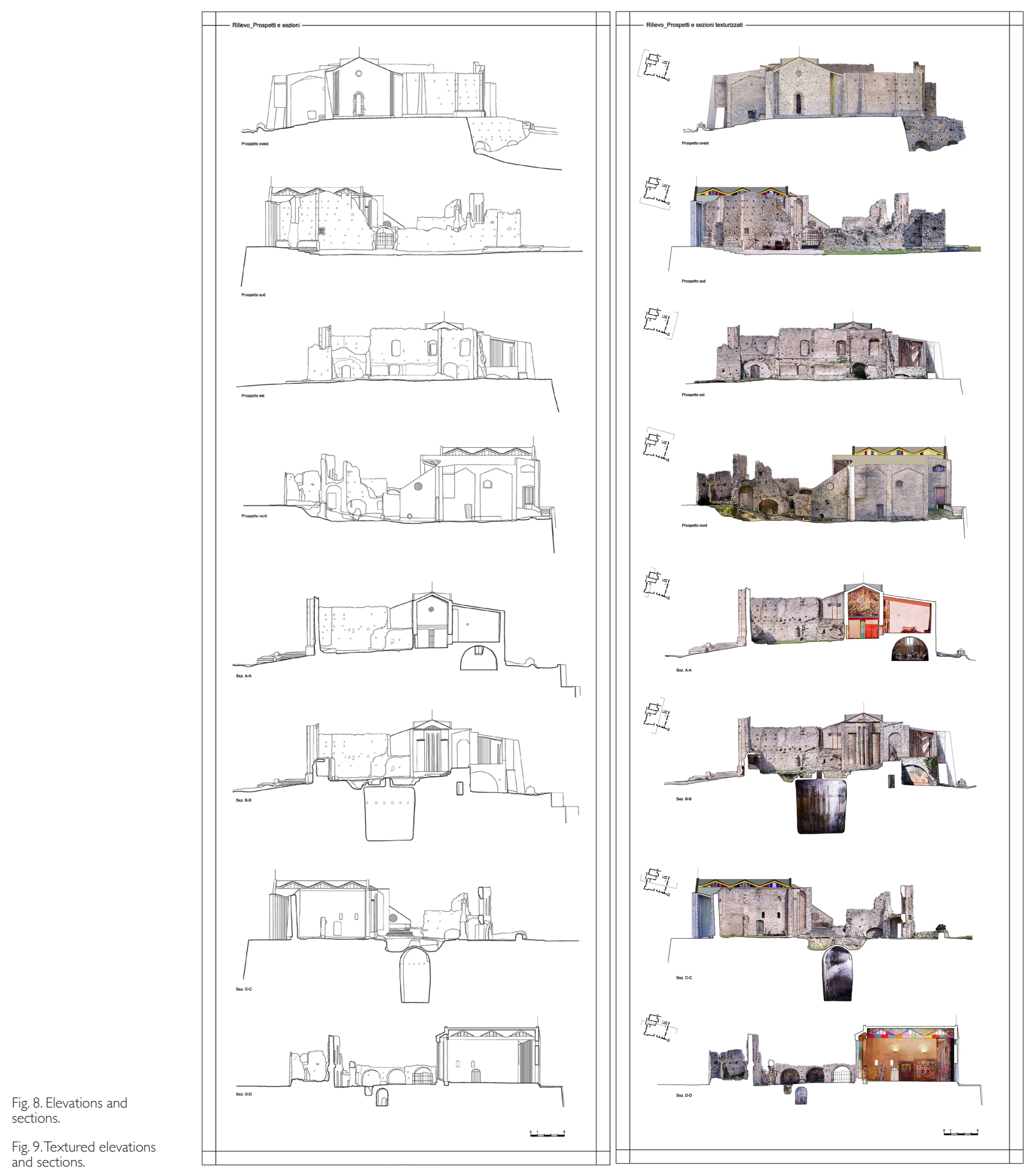




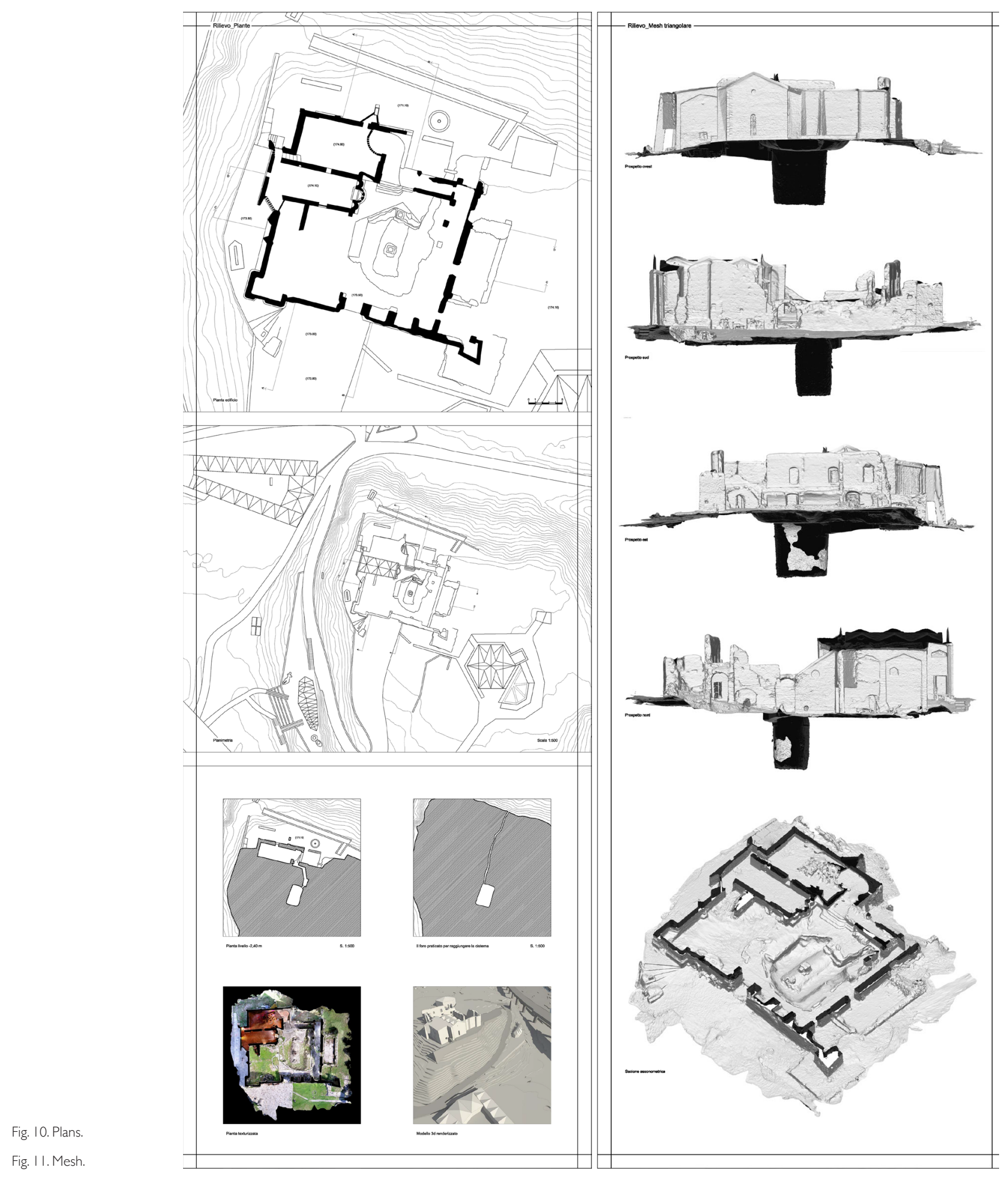


containing the colour information generated, to then create and texturize the mesh (fig.6), with a resolution of 2.986 .269 fronts.

The result was pretty much homogeneous, accurate in the measurements and well enough structured for the post-production phase, even in the areas of hard accessibility, like the 2 walls belonging to the underground tank and the roofing of the small church.

For the church roofing it was decided not to use other tools such as UAV or 3D Eye, since the latest renovations were quite new and the relevant information to draw these portions was already available from other sources.

The deliverables generated using an SFM software have been afterwards enhanced using CAD and other tools used to handle raster imaging. The four elevations have been finally designed: four sections and the map of the building (figs. 8, 9, 10). These compositions have been added to a digital database, that includes mesh (fig. 7) clouds (fig. II) and photographic records.

\section{Notes}

[I] A connection between relief and history, where the historical investigation and the survey become integral parts of a single operation. A temporal connection between the past and the present sewn together by the thread of art. A physical connection between east and west, marked by the Torbido torrent as a way of communication between the lonian shore and the Tyrrhenian shore.

[2] Among the results of the relationship between the author and the place, see the interdisciplinary degree thesis discussed in March 2019 at the Mediterranea University of Reggio Calabria (department dArTe), with the name L'enigma del museo Santa Barbara - Tra archeologia e contemporaneità. Supervisors: prof. Gaetano Ginex, prof. Ottavio Amaro. Co-Supervisor: Nik Spatari; student: Francesco Stilo.

[3] On this point, it's interesting to note how the Torbido valley, due to its own morphology, has represented a stable pathway of connection across times: today, with the construction of the state road Strada Grande Comunicazione Jonio-Tirreno, we witness a true evolution from that ancient path, where the homo primigenius and his flocks of sheep used o go around, to a viaduct that is now the symbol of this valley and the primary connection between the west and the east side of the region.

[4] "Mense maio, indictione II, anno 6647. Cum ego Hugo Habbas sanctae Trinitas Venusinae essem in (monasterium) S. Phantini Praetoriati, venisti coram me tu dominus Leo notarius S. Nicodemi, et petiisti a me, ut traderem tibi ex legitimi possessionibus monasterii S. Phantini, videlicet (aliquod) ex agrestibus olivetis, ut oleastros insereres sub praestatione. Ego autem tuis precibus motus observitia et beneficia quamplurima, quae praestitisti monasterio et nobis, dedi tibi agreste olivetum proximum oratorio S. Phantinis veteris. Ipsius autem fines sunt: ab oriente sepes praedii praedicti S. Phantini, et discendi recta per sepem hortius que ad viam; ab occidente vero glarea, que descendit a monte, et Criza; a septentrione duo Armi; a meridie via et oleaster maior. Solvere vero ipse tenearis pro memorato (praedio) quotannis monasterio S. Phantini cannatam olei et nihil amplius".

[5] "Inventarium omnium bonorum que tenet et possidet monasterium Santi Stefani Prothomartiris de Boscho, ordinis Cartusiensis, in grangia terre Agropterie, que grangia consistit in tribus eclesiis positis in territorio dicte terre, una sub vocabulo Santi Fantini, alia sub vocabulo Sante Marie de Burri et alia sub vocabulo Sante Barbare, que bona, tam domanialia ipsius monasterii, quam emphiteotica, fuerunt inventariata, citatis emphiteotis et hiis quorum interest et relatis prout in actis curie".

[6] Pietro De Leo, 1992. Per l'identità storico monumentale del complesso di Santa Barbara in Mammola. A note of the department of History of Università della Calabria in December 1992.

[7] "Bona emphiteotica existentia in grangia santi Fantini in territorio terre Agropterie. In primis dictum monasterium tenet et possidet in eius dominio et potestate, ecclesiam unam, sub vocabulo Santi Fantini, que ecclesia est caput dicte grangie et est nunc diruta et apparent solum vestigia murorum dirutorum, que ecclesia est exempta ab omni iuridicione episcopale et presertim Yracensi et pro ut per privilegia antiqua nobis presentata clare constat fuit dicto monasterio concessa cum omni plenitudine potestatis, tam in temporalibus, quam in spiritualibus et est sita e posita in dicto territorio terre Agropterie, confinata iuxta flumen antiquitus nominatum Prothoriate, quod nunc vulgariter dicitur Flumen Turbidum et iuxta terras ex omni parte dicti monasterii"'.

[8] Perimeter e external elevation, cloister and interior elevation, interiors of the church and of the exposition room, underground areas.

[9] It has been used a personal computer: CPU AMD FX8350 Eight Core 4 Ghz; 24 Gb RAM; graphic card AMD Fire Pro W5 100.

\section{Acknowledgements}

I thank Nik Spatari and Hiske Maas for the demonstrated availability and for the possibility offered me with respect to the study and knowledge of MuSaBa, the Palmi "D. Topa" library, all those who have offered me precious support and collaboration. 


\section{References}

Balbo Pier Paolo, Bianchi Alessandro, Cervellini Francesco et al. (1993). Per un atlante della Calabria. Roma: Gangemi Editore. Barillaro Emilio ( 1977). II complesso monastico di Santa Barbara in quel di Mammola. In Brutium, n. 3-4, a. LVI, pp. I5- I8.

Barrio Gabriele ( 57 I). De antiqvitate et situ Calabriae libri qvinqve. Roma: De Angelis.

Bertocci Stefano, Bini Marco (2012). Manuale di rilievo architettonico e urbano. Torino: Città Studi.

Calogero Giuseppe (1964). Storia e cultura della Locride. Messina: ed. La Sicilia.

De Leo Pietro (a cura di). (1998). La platea di S. Stefano del Bosco. Soveria Mannelli: Rubettino.

De Luca Livio (200 I). La fotomodellazione architettonica. Palermo: Flaccovio edizioni.

Gallucci Giuseppe (1978). Finalmente individuata in quel di Mammola la località del monastero di S. Fantino Pretoriate. In Brutium, n. 2, a. LVII, pp. I8-19.

Gallucci Giuseppe (1980). Un oratorio basiliano dimenticato in contrada S. Barbara di Mammola. In Brutium, n. 4, a. LIX, pp. II-13.

Gallucci Giuseppe (1983). Notizie storiche sul monastero di S. Fantino Pretoriate e sul complesso murario della grancia di S. Barbara in quel di Mammola. In Brutium, n. 4, a. LXII, pp. 2-5.

Gallucci Giuseppe (2009). II monastero di San Fantino Pretoriate (note sulla Grancia di Santa Barbara). In Calabria Sconosciuta, n. 124 , a. XXXII, pp. 35-38.

Ginex Gaetano, Trimboli Francesco, Mercurio Sonia, Stilo Francesco (2019). II limes della Calabria bizantina. Tracce, percorsi e vie. In Archistor extra, 6, 2019 , pp. 214-227.

Giustiniani Lorenzo ( 18 | 6). Dizionario geografico ragionato del regno di Napoli. Napoli: Stamperia Giovanni De Bonis.

Lupis Crisafi Domenico (1887). Cronaca di Grotteria: dalla sua fondazione fino all'anno 1860. Gerace Marina: Tip. Michele Caserta \& C.

Marafioti Girolamo (I60 I). Croniche et antichità di Calabria. Padova: Ad istanza de gl'Vniti.

Saletta Vincenzo (1969). San Nicodemo del Cellerano. In Studi Meridionali, fasc. III-IV, a. II.

Santagata Giuseppe (2005). Compendio storico-artistico della monumentalità chiesastica calabrese. Locri: Pancallo Editore.

Stilo Francesco (2019). L'enigma del museo di Santa Barbara. Tra archeologia e contemporaneità. Tesi di Laurea in Architettura Università degli Studi Mediterranea di Reggio Calabria. Relatori: prof. Gaetano Ginex, prof. Ottavio Amaro; correlatore: Nik Spatari.

Trinchera Francesco ( 1 865). Syllabus Graecarum Membranarum. Napoli:Typis Josephi Cataneo.

Zavaglia Vincenzo (1973). Mammola. Chiaravalle Centrale: Frama Sud.

\section{Author}

Francesco Stilo, Università degli Studi Mediterranea di Reggio Calabria, francesco.stilo@unirc.it

To cite this chapter. Stilo Francesco (2020). L'enigma del monastero di Santa Barbara. Tra storia e rappresentazione/Santa Barbara's monastery enigma, between history and representation. In Arena A., Arena M., Brandolino R.G., Colistra D., Ginex G., Mediati D., Nucifora S., Raffa P. (a cura di). Connettere. Un disegno per annodare e tessere. Atti del $42^{\circ}$ Convegno Internazionale dei Docenti delle Discipline della Rappresentazione Connecting. Drawing for weaving relationships. Proceedings of the 42th International Conference of Representation Disciplines Teachers. Milano: FrancoAngeli, pp. 2736-2757. 